\title{
The Recurring Conquest of Hearts and Minds: Reflections on Totalitarian Currents in Education
}

\section{Pádraig Hogan ${ }^{a}$}

a National University of Ireland Maynooth Education Department padraig.hogan@mu.ie

DOI 10.15240/tul/006/2021-1-012
Authoritarian Precedents:

a European Historical

\section{Background}

Paternalistic or authoritarian conceptions of education have been quite common, even dominant, in the history of Western civilisation. For ten

centuries of Western history, roughly from the 9th to the 18th century - or from Charlemagne to the French Revolution - virtually all formal learning fell under the control of the Christian church. I should stress that "Christian Church" here does not mean the diverse communities of believers that characterised Christianity in the early centuries after the death of Christ. It refers, rather, to the powerful institution that the church became from the fourth century A.D. onwards, after Emperor Constantine favoured Christianity over the traditional pagan religions of the Roman world. With this historic development Latin increasingly became the language of learning throughout Western civilisation. ${ }^{1}$ Hand-in-hand with this, the papacy achieved the most far-reaching supervision over what could be thought and what could be taught. During the five centuries from Constantine (Emperor 306-337) to Charlemagne (Emperor 800-828) Christianity became a defining

1 By Western civilisation I mean all the countries of Europe that inherited foundational cultural influences from Greek and Roman origins and from Christianity, together with the decisive spheres of influence of this civilisation in the wider world from the late 15 th century onwards - e.g. America, Australia. 
institution of Western culture and education. Equally important was the kind of Christianity that became foundational for the West, i.e. what happened to the heart of Christianity itself as this institutionalisation was accomplished. Among the many factors that played a part in this story, two are decisive from an educational point of view and it is worth looking briefly at each.

The first factor is the replacement of the diverse early Christian communities with a uniform set of doctrines that came to achieve a monopoly status (MacCulloch, 2009, Ch. 6; Freeman, 2009, Chs. 23-24). Adding to the Council of Constantinople (381) and the Council of Nicaea (325), Emperor Theodosius decreed in 381 that the orthodox contents of the Nicene Creed were to identify the sole religion of the Empire. All other religions, moreover, were to be banned. The second factor was no less far-reaching. It concerns the moral teachings of the new orthodoxy. These signified a decisive shift of emphasis from god-loving to god-fearing: from the priority of the twofold command to love God and neighbours to a priority with human sinfulness and waywardness, and with the need to combat these. The theology of Augustine of Hippo (354-430) was crucial here, as it shaped the essentials of the kind of Christianity which was in time to become firmly established throughout Europe. From Neoplatonism Augustine adopted some of the basic features of his theological outlook. These included an upper world of eternal truth and beauty and a lower world of sensual desires and illusory honours. Already here we can see the basic structure for his major work The City of God, with its striking contrasts between a heavenly city and an earthly city. He tells in his Confessions that he was drawn to an ascetic Christianity which convinced him that his previous life had been enslaved to sinfulness. The following passage from Book VIII of Confessions reveals the ecstatic character of that asceticism.

"I had turned my eyes elsewhere, and while I stood trembling at the barrier, on the other side I could see the chaste beauty of Continence in all her serene unsullied joy, as she modestly beckoned me to cross over and to hesitate no more. 
She stretched out loving hands to welcome and embrace me, holding up a host of good examples to my sight."

(1986, p. 176)

For Augustine the lower world, or earthly city, was not merely a cavelike realm of illusory beliefs and pleasures, as it had been for Plato. More importantly it was a morally depraved world; an evil place of sensual lusts, from which its captives could be rescued only by throwing themselves prostrate before the undeserved grace of God. In this theology the darker themes of St. Paul's Letter to the Romans ("I know that good does not live in me") were given a prominence that frequently overshadowed the emphasis on compassion and reconciliation in the four Gospels of the New Testament. The institutionalising of this rather severe theology in Latin Christendom became decisive in the following centuries.

As Latin Christendom expanded northwards and westwards after the barbarian invasions it also became the distinctive cultural context for formal education and higher study. Latin was the language of learning and schools were typically attached to monasteries, or cathedrals. Control of education was thus secured by the Church hands for many centuries. An extensive supervision of both texts and masters kept a vigilant eye on any thoughts or teachings that might be regarded as heresy. Even bold spirits who were not easily intimidated could be dramatically brought to grief. The condemnation of Peter Abelard's works by the Council of Sens in 1140 serves as a striking example of how a leading thinker and teacher could be ruined (Clanchy, 1999). Similarly revealing are research studies of the condemnations of the University of Paris curriculum in 1277, and of the maintenance of theological orthodoxy in the emerging universities (Grant, 1982; Thijssen 2018). Learning was highly regarded in Medieval Europe, but the tenor of that learning settled into well-trodden paths that were, for the most part, more compliant than venturesome.

The Reformation that began with Martin Luther's revolt in 1517 produced sudden shocks to the long-prevailing authoritarian pattern in the pursuit of learning. Luther vehemently asserted his desire to be 
free of the shackles of papal theological authority. His refusal at the Diet of Worms (1521) to recant his 95 theses was a remarkable act of fearlessness in the face of the by now awesome power of the papacy. But ultimately, Luther's break with Rome led to new forms of custodianship in education. So did the breaks of other reformers, such as Calvin in Switzerland and Knox in Scotland. The reformulation of their own teachings by the newly sectarian forms of Christianity made these teachings doctrinally more exact, and also more exacting. The Catholic Counter-Reformation, powerfully launched by the Council of Trent (1545-1563), added its own influential contribution to this. The Reformation, and the Catholic reaction to it, reinforced authoritarian outlooks - mutually hostile outlooks at that - within the now separate Christian churches. These developments ultimately advanced a vigorous restoration of a long-standing custodial order of things, as distinct from the Reformation's early promise of a removal of oppressive constraints on learning and teaching.

Later generations of educational thinkers, inspired by Rousseau (1712-1778), Kant (1724-1804), Pestalozzi (1746-1827) and others, sought in their different ways to advance an understanding of education as an emancipation of mind and heart. These efforts envisaged the cultivation of a capacity for independent thought, of an ability to question, of a willingness to contribute that would benefit others, oneself and society more widely. And it is true that this pioneering tradition of pedagogical research remains fertile, if frequently embattled, in our own day. It is also true that in the aftermath of the Enlightenment and French Revolution, church control of education was increasingly challenged, but chiefly by secular forces that regularly proved to be as overbearing as their clerical predecessors. For instance, Napoleon's scheme for nationwide education in France established new precedents and showed that a centralised state power could be as hierarchical as anything in the Ancien Régime had been. In fact, in many countries, the nineteenth century battles between church and state to influence the aims and curricula of schools resembled the replaying of an old tune in a new key. In keeping with the political or religious outlooks of the controlling powers, teachers and school leaders regularly had 
to comply with draconian constraints and inspections, and sometimes with restrictions on their personal lifestyles. Yet, there often remained, for teachers who were so inclined, some scope to take pedagogical initiatives locally; to allow some measure of curricular venturing, however limited this might be. Something more intrusive and more vehement was coming however, with the arrival in the arena of education of the mass ideologies of the twentieth century.

\section{Fascism and Totalitarianism}

Four major new ideological movements came to pervade education in countries like Italy (Fascism), Spain (Falange-Francoism), Germany (Nazism) and the Soviet Union (Stalinism) in the first half of the 20th century. The first three were all variants of fascism while the last was a severely doctrinaire version of Marxism, but one that had adsorbed some fascist ideas. In each case the ideology attempted to define anew what it meant to be Italian, Spanish, German or Russian. But the manner in which they did so was totalitarian, not merely authoritarian. That is to say, there was a relentless drive to compel every individual to embrace the official characterisation of personal and national identity being propagated. This compulsion produced forms of surveillance that were as intolerant in their understanding of differences in belief and outlook as they were comprehensive in their reach into people's lives. That reach extended not only to those who were active in politics, trade unions, or various forms of community activism. It also permeated cultural and sporting organisations, workplace communities and not least individual households.

Of the three fascist ideologies, the first to take root was Italian Fascism (with a capital F in Italy), associated with Mussolini's take-over of power in 1922. The rationale for Italian Fascism owed much to Giovanni Gentile (1875-1944). Gentile, already internationally known as a philosopher, became Minister for Public Instruction in 1922. He co-wrote The Doctrine of Fascism with Mussolini, and also penned a number of other pro-fascist documents. Gentile was a Hegelian philosopher who rejected the materialism of Marxist interpretations of Hegel. He was drawn instead to the possibilities of the Hegelian notion of "spirit" 
(Geist) to renew an Italy and a wider Europe which he perceived as civilisations in decline. In the notion of "spirit" Gentile saw an immensely powerful motivating principle for action: one that combined a captivating idealism with a proud nationalism, based on inspirations from a glorious imperial past. And the "spiritual attitude" of fascism envisaged something new: a "totalitarian" organisation of society, introduced in The Doctrine of Fascism in the following words:

"The Fascist conception of the State is all embracing; outside of it no human or spiritual values can exist, much less have value. Thus understood, Fascism, is totalitarian, and the Fascist State a synthesis and a unit inclusive of all values - interprets, develops, and potentates the whole life of a people." (Mussolini \& Gentile, 1932, p. 2)

This meant that there would be "no individuals or groups (political parties, cultural associations, economic unions, social classes) outside the State" (p. 2). Gentile saw nothing sinister in this conception of the State (always with a capital S). It was through the State that the proudest ideals of nation and fatherland received their vital character and preserved their uplifting attractiveness for the hopes of the people. As distinct from "that form of democracy which equates a nation to the majority", Fascism was to be seen as a supremely unifying force, "advancing, as one conscience and one will, along the self-same line of development and spiritual formation" (p. 3). Accompanying this aggressive conception of identity were the twin notions of self-sacrifice and militarism.

"Fascism does not, generally speaking, believe in the possibility or utility of perpetual peace. It therefore discards pacifism as a cloak for cowardly supine renunciation in contradistinction to self-sacrifice. War alone keys up all human energies to their maximum tension and sets the seal of nobility on those peoples who have the courage to face it." (p. 4) 
Denunciations of liberalism, positivism and democracy feature prominently in Italian Fascism. What is absent from its documents in the early 1930s, however, is any targeting of a particular group, for instance Jews, as a prime enemy, although this was to change by the end of the decade. In Spain the Falange movement, founded in 1933 by José Antonio Primo de Rivera (1903-1936), promoted a characteristically Spanish kind of fascism, echoing strongly the main features of its Italian counterpart. These included: liberalism and democracy as discredited ideals; the state as that which gives vitality and virility to the ideals of nationhood and fatherland; the state as a unitary and supreme force. Any form of Communism was repulsive to the Falange's conceptions of Spanish tradition. This stance was potentially explosive, as a popular front of disparate left-wing republican parties had won the Spanish General election of February 1936. Just five month later, an uprising of rightwing forces against the government started the Spanish Civil War.

As in Italy, Spanish fascism viewed itself as a spiritual source for the resurrection of a unique national identity-imperial, Catholic, and indeed masculine in character. As warlike as the Italian version, Spanish fascism had an additional passion and intensity, a consciously romantic allure, as the following extract from the speeches of Primo de Rivera illustrates:

"Our place is in the open air, beneath a clear night, embracing a rifle, with the stars high above. Let the others carry on with their feasts. We are outside, in a tense vigil, fervent and confident, we anticipate the dawn in the joy of our beings."2

2 PRIMO De RIVERA, José Antonio, 1933/2020. “Discurso de José Antonio Primo de Rivera exponiendo los puntos fundamentales de Falange española, pronunciado en el Teatro de la Comedia de Madrid, el día 29 octubre de 1933”. Full text available at: http://www.segundarepublica.com/index.php?opcion=6\&id=78. The extract I have quoted in English is the concluding sentence of the speech: "Nuestro sitio está al aire libre, bajo la noche clara, arma al brazo, y en lo alto, las estrellas, Que sigan los demás con sus festines. Nosotros fuera, en vigilancia tensa, fervorosa y segura, ya presentimos el amanecer en la alegría de nuestras entrañas”. 
Following the execution of Primo de Rivera by Republican authorities in November 1936, the influence of the Falange on the nationalist (anti-republican) side grew immensely during the Spanish Civil War. It was a marginal political force before the war. But Franco's endorsement and subsequent recasting of its ideals set the foundations for the dictatorship that began with the final defeat of the Republicans in April 1939 and continued until Franco's death in 1975.

The intolerance evident in Italian and Spanish fascism became even more emphatic in the case of German fascism. In this instance, the national ideology did not merely deny individuals a right to affirm a sense of German identity that differed from the Führer's conception. The state continually asserted its power to seek out such differences, by using terror where expedient, and to eliminate them. Underlying all of the Nazi Volk rhetoric, summoning Germans to arise and embrace the superior destiny of their race, lay the relentless, calculating machinery of terror. This machinery was turned with particular violence on Jews, but few who resisted the Nazi order of things could hope to escape its ruthless reach. Education was to have a strategic importance in shaping and maintaining this new order.

It was in the Soviet Union under Stalin however, and later China under Chairman Mao, that totalitarianism achieved its most complete scope and effectiveness. China lies outside our scope here, but focusing on the Soviet example shows how key strands of fascist thinking became embodied in the kind of Communism that took root with Stalin's rise to power in the USSR (1922). Two of these strands became prominent in Stalinism, and they reveal the mendacity of Soviet claims to have won a liberating war against fascism in 1945 . The first strand concerns nationalism. The second concerns the State and the question of individual identity. In relation to the first strand, one of the defining features of classical Marxism is its international character; international not in any imperial or colonial sense, but in the sense of seeking to liberate workers worldwide who were oppressed by deeply ingrained practices of capitalism. Far from affirming the different identities and languages of the various "republics" that constituted the Soviet Union, Stalin imposed an official Russian identity as superior and predominant. 
This "Russification", which replaced a previous policy of cultivating local ethnic identities (korenizatsiia) was accomplished mainly from 1932 onwards, not least through an extensive control of curricula and textbooks in schools (IDFI, 2019). In relation to the second strand, education was given a central role - in schools and in youth movements (Komsomol) - to ensure that younger generations became loyal members of the Soviet state and to eliminate "anti-Soviet counter-revolutionary sentiment". Recent archival research, including evidence from Stalin's own native "republic" of Georgia, shows how Soviet totalitarianism had incorporated key elements of fascism and made them its own. Any failures by school leaders to align the school's work with the official doctrines of the all-powerful state could lead to a summary trial and the "repression", or execution, of the persons accused (IDFI, 2019).

\section{Totalitarianism and Education}

Examples like those reviewed in the previous two sections serve to illustrate that authoritarianism is not the same as totalitarianism. Fascism, from Mussolini and Gentile onwards, is totalitarian, if not always overtly so. Sometimes the difference between authoritarianism and totalitarianism may be one of degree, rather than a difference in kind. But where education is concerned, a predominance of actions like the following indicates that a system of schooling is more totalitarian than authoritarian in character: the systematic alignment of school curricula and textbooks to the State's doctrines and directives; the infiltration of the teaching profession, and of teacher education institutions, by state-sponsored agents of surveillance; the wide-scale mobilisation of youth though closely monitored ideological and physical training programmes; the official propagation of ideas like "the formation of the Soviet man" or "the formation of the new man", as if these were naturally educational ideas; the denouncing of non-compliant colleagues, publicly or secretly, to the state authorities; the punishing of alleged infringements committed by teachers or students through an intensive machinery of interrogation and terror; the selection and advanced propaganda training of future leaders in elite, state-run academies. 
This list of actions is drawn from concrete practices that give a totalitarian character to the conduct of education. It is a representative rather than an exhaustive list. Such actions range from Spain in the West to the Soviet Union in the East, from Latvia in the north to Greece in the south, with a concentration in Central and Eastern European countries. From a philosophical perspective, I believe that Hannah Arendt's monumental study The Origins of Totalitarianism (first published in 1951) offers an illuminating background for reviewing some of the key issues. In that study Arendt identifies important features that distinguish totalitarianism from previous forms of tyranny in Western history. The following are some of these features - ones that make totalitarianism particularly important to understand from an educational perspective:

1. It seeks to wipe out the individuality of each person, harbouring a particular suspicion of artists and intellectuals, whose work regularly undermines the best efforts of propaganda.

2. It seeks to remove the dignity and personal privacy of individuals on a mass scale.

3. It furnishes instead a sense of identity that is largely ready-made, and embodied in a powerful either/or doctrine: e.g. true patriot or enemy of the people.

4. It advances its influence and power by representing politics as a mass movement of the loyal that denounces any opposition.

5. It involves a vast use of undercover surveillance to make whole populations conform through fear, or even terror. (Arendt, 1951/1968, Ch. 12).

Any conception of educational practice that embodies features such as these goes well beyond the traditional kinds of authoritarian education we reviewed in the opening section. Such traditional conceptions viewed education primarily in terms of transmission - of beliefs, of values, of preferred forms of knowledge. The main underlying purpose was to pass on to younger generations traditions that were handed down through many previous generations, sometimes by renewing them in radical ways and providing new directions for the future; for instance 
the efforts of Luther and Melanchton on the one hand, or those of Rousseau or Kant on the other. Totalitarianism by contrast, regards education not in terms of transmitting a cultural heritage, whether a renewed one or not. Rather its purposes are those of removal and replacement, drawing on the most resourceful forms of compulsion and violence to accomplish its goals. In this respect it recalls one of the most questionable remarks in Plato's writings - a remark that carries a chilling shock if taken literally: "They will take the city and the characters of men, as they might take a tablet, and first wipe it clean" (Republic, 501a). The political presumption that such a wiping-clean is in fact possible, reveals the drastic educational import of totalitarianism. So also does the presumption that public education can replace the demolished social order with a radically different one, tailored to a newly-conceived design and implemented through a series of oppressive enforcement plans. Apart from the historical impossibility of success with such goals, we are confronted here with an effort at the total removal of education as a kind of endeavour that has its own possibilities and responsibilities. I would now like to explore that very endeavour more closely, if also briefly.

\section{Public Education as a Practice in its own Right}

The ancestry of the idea of education as a practice in its own right, at least in Western civilisation, reaches farther back than Aristotle and Plato. It can best be found in the collective enquiries of Socrates and companions in the Agora and other public places of ancient Athens, as disclosed in the earlier, though not the later, Dialogues of Plato. As a practice in its own right, education is committed to the idea that each human being is unique; that each has her/his own way of being human, and of becoming more so, through sustained engagement with rich inheritances of learning (e.g. scientific, artistic, mathematical, literary, religious, musical, historical etc.). Such a practice, or family of practices, cultivates learning environments where each pupil is helped to discover her own most promising pathways; to learn to negotiate successfully her own strengths and limitations. 
Such a practice moreover is much less concerned with transmission than it is with encounter. Preoccupation with transmission - whether of cultural heritage, of moral and religious values, of knowledge and skills etc. - quickly throngs the arena of educational discourse with controversial questions: Whose heritage? Which religious and moral values? What knowledge and skills? Such matters are not irrelevant of course. But making such questions the primary point of departure yields too much of the educational arena itself to ongoing conflicts, and to the combative energies they stimulate and consume. Such preoccupations curtail, even obscure, a more fruitful kind of educational undertaking, namely the core purposes of education as a particular kind of encounter. The notion of encounter, as distinct from transmission, envisages educational practice as an emergent interplay between human experience on the one hand and a range of inheritances of learning on the other. If this initially sounds like an abstract notion it must be replied that it captures more accurately what goes on in classrooms anyway, whether in successful or disfigured forms, than does any notion of transmission. Students always take some attitude to what is addressed to them boredom, enthusiasm, rejection etc., whether that attitude is manifested in some physical reaction or experienced silently. Dewey called this “collateral learning" (1938/2008, p. 48), and stressed that it is crucially important in the longer run. That is to say, the attitude that is evoked, or provoked, in the student may have a deep and enduring influence. It predisposes the student, this way or that, in any further lessons with the teacher or subject in question. Being alert to what happens in "collateral learning", to its possibilities as well as its pitfalls, enables teachers to realise that an immense amount of what is merely transmitted may fall on infertile ground.

The purpose of encounters that are properly educational is to enable the student - in a sustained and progressive way - to discover something of the historian in himself, or something of the scientist in herself, or something of the linguist, craftsperson, mathematician; or something of a religious sensibility; or more broadly, some authentic combination of these. Here, subjects are seen less as knowledge to be mastered than as inheritances of learning, from the classical and 
ancestral to the avant garde; each inheritance having its own internal riches and tensions. For an educational encounter to be fruitful, an inheritance of learning must first be alive in a teacher. It seeks to come to voice through the practice of a teacher and thus to uncover and engage those potentials that are most native to the plurality of participants in a particular learning environment. Equally important, it is through the quality of learning practices themselves that any skills or values of enduring importance come to be appreciated and internalised. They cannot be just transmitted. This also means that anything of enduring importance in moral education, or in the cultivation of co-operative capabilities, arises from the quality of the learning experience itself. The real ethos of education is thus more related to the successes and failures in the joint efforts of teachers and students than to any aims of transmission that are prescribed from above or outside. This remains the case no matter how worthy or admirable such aims might be. In short, genuine educational practice promotes an unforced discovery of personal identity and capability. It does not put either onto pre-ordained pathways; whether those of a church, a political party, or other institutionalised interest.

Two key ideas in Arendt's The Human Condition, "natality” and "plurality", are particularly pertinent to the characterisation just drawn. "Natality" signifies not only the fact of new birth, but also, in each case, that "the newcomer possesses the capacity of beginning something anew" (1958, p. 9). "Plurality," in Arendt's own words, "is the condition of human action because we are all the same, that is, human, in such a way that nobody is ever the same as anyone else who ever lived, lives, or will live” (p. 8). As core characteristics of educational practice, natality and plurality involve engaging with inheritances of learning in ways that open up new imaginative neighbourhoods. Educational practice involves countless ways of disclosing to students the manifold character of their own emergent identities. Educational practitioners here - as teachers, school leaders, or researchers - are dedicated first and foremost to promoting a profusion of human flourishing. 
On the analysis presented here then, education as a practice in its own right involves precisely the reverse of the main features of totalitarianism identified by Arendt.

1. It seeks to cultivate the individuality and communicative capability of each person.

2. It seeks to build learning communities where participants learn to understand the reality of human difference and the right to be different; also to respect the personal dignity of each.

3. It enables each student to uncover something of the historian in herself, or the scientist, the linguist etc., thus gradually disclosing a sense of identity and capability that is fulfilling and sustaining.

4. It practises teaching and learning through daily actions that allow ideas like justice, plurality, tolerance and excellence to be made manifest in experience, and thus to take deeper root.

5. It encourages the development of a healthy scepticism of the claims of institutions, particularly where such claims involve invasive features like surveillance or lack of transparency.

Policies along lines such as these just listed feature to a greater or lesser extent in the discourse of educational policymaking and in the pedagogical actions of schools in most democracies today. In few countries however are such features the prevailing ones in the educational system as a whole; and in many cases such aspirations are "honoured more in the breach than in the observance". There is evidence moreover of some counter-trends. These are most frequently associated with neoliberal outlooks of many democratic governments today, particularly where such outlooks are combined with uncritical conceptions of "evidence-based" policy. I would like to conclude by identifying some emergent concerns from this milieu - concerns the betoken the re-appearance on the horizon of potentially new forms of mass captivity in the recurring conquest of hearts and minds.

\section{New forms of Conquest?}

With the collapse of the "Iron Curtain" from November 1989 onwards, one might initially expect that educational practice in the former Soviet 
satellite countries might become freer to manage its own affairs. Such discretionary scope had been a notable feature of the educational systems of many Western democracies, especially from the mid 1960s to the mid 1980s. But by the end of the 1980s this tolerant order of things was decisively confronted by a strident new political orthodoxy in the West. This sprang from the Thatcher-Reagan ideological axis, combining a fervent commitment to the privatisation of public services with a newly-coercive centralisation of political power. The results of this major shift were dramatic on an international scale in the early 21st century, not least where educational policy was concerned. With notable exceptions (e.g. Finland, to some extent Ireland and Scotland), the international tenor of educational reform in recent decades has detrimentally reshaped public education. This reshaping makes education again an essentially submissive practice, conforming firstly to the demands of the current party or administration in power. Policy-borrowing, or policy-imitation, based on this new orthodoxy, became extensive in Western countries as these reforms spread. By the time some former satellite countries looked Westwards for democratic exemplars in educational policy, the influential models of the sixties and seventies had been largely eclipsed be the international predominance of neoliberal policies.

A curious pattern is evident here: the widespread decline in democracies of the democratic idea of education as a participatory, co-operative and semi-autonomous endeavour. What replaces it is an endeavour that equates quality in education with the notion of indexed quantity (of grades, scores etc.), and that values competitive ranking as the best means of carrying out evaluations. This new pattern requires, on an unprecedented scale, the gathering of data that can be readily indexed and compared; especially data on performances of schools, of teachers, and of individual students. What lies essentially beyond the scope of such data-gathering is nothing other than the educational heart of the matter: the experience of teaching and learning itself, in its inherent individuality and diversity.

Currently, many educational research studies are exploring features of this decline, and its harmful consequences for educational 
practice. Important themes in such research include the following three: (a) critical investigations of the propagation by international bodies like the OECD and the World Bank of new models of the "good teacher" models devoid of context or historical reference (Robertson \& Sørensen, 2018); (b) penetrating revelations of the widescale "datafication" of teachers, i.e. the electronic tracking of their work and the systematic use of data to promote compliance and conformity (Lewis \& Holloway, 2019); (c) analysis and review of the use of value-added models (VAMs) that claim to determine the worth of individual teachers for purposes of reward, penalty, or remediation (Amrein-Beardsley \& Holloway, 2017).

While trends such as these three hardly amount to new forms of totalitarianism, they clearly signify a recurrence of historic authoritarian impulses in education, but now on a global scale. One can moreover see in the rise of digital surveillance of teachers' practice something tyrannical in an embryonic sense; something that ominously recalls the final feature of Arendt's characterisation of totalitarianism. Of course this rise in digital tracking is not accompanied by any of the traditional machinery of terror. It does not need to be, as fear can insinuate itself here in less blatant, yet powerful forms. For instance, fear that one's distinctive contributions a teacher will be ignored and that one will be passed over for promotion in favour of one's higherranked conformist colleagues; or fear as a school principal that the school's caring initiatives will count for nothing, and that the school will lose funding, if performance indicators for students and teachers aren't as good as, or better than, last year's. And what goes for individual teachers and schools in this regard may also go for educational policymaking at a national level. This becomes more likely to the extent that predominance is given to the country's participation in high-stakes initiatives like the PISA programme of the OECD.

Any lasting release from burdens such as these just considered is crucially connected with the necessity to acknowledge public education as a distinct practice in its own right; not as a subordinate or submissive endeavour to the state, or church, or other institutional interest. But let us be clear: this does not mean some kind of absolute independence for educational practice. As a practice in its own right, education 
is properly answerable to the public for the fruits of its labours, and for how it uses the resources it receives from the public purse. For its part however the state, as guarantor of the public interest, is responsible inescapably responsible - for safeguarding the integrity of educational practice. This represents a political challenge that is to be embraced rather than evaded by democracies. It is also bad news for any inclinations of a totalitarian kind.

\section{References}

AMREIN-BEARDSLEY, Audrey \& HOLLOWAY, Jessica, 2017. Value-Added Models for Teacher Evaluation and Accountability: Commonsense Assumptions. Educational Policy. Sage, 33 (1), pp. 1-27. ISSN 0268-0939.

ARENDT, Hannah, 1958. The Human Condition. Chicago: The University of Chicago Press. ISBN 0-226-02593-4.

ARENDT, Hannah, 1951/2017. The Origins of Totalitarianism. London: Penguin. ISBN 9780241316757.

AUGUSTINE of Hippo, 1998. The City of God against the Pagans. Translated by R.W. Dyson. Cambridge: Cambridge University Press. ISBN 0521464757.

AUGUSTINE of Hippo, 1986. Confessions. Translated by R. S. Pine-Coffin. New York: Dorset Press. ISBN 9780880291033.

BROWN, Peter, 2000. Augustine of Hippo. London: Faber and Faber. ISBN 9780571204953.

CLANCHY, Michael T., 1999. Abelard: A Medieval Life. Oxford: Blackwell Publishers. ISBN 0-631-21444-5.

DEWEY, John, 1938/2008. Experience and Education. New York: Touchstone. ISBN 978-0-684-83828-1.

FREEMAN, Charles, 2009. A New History of Early Christianity. New Haven and London: Yale University Press. ISBN 978-0-300-12581-8.

HARGREAVES, Andy \& SHIRLEY, Dennis, 2012. The Global Fourth Way: The Quest for Educational Excellence. Thousand Oaks CA: Corwin. ISBN 978-1-4129-8786-8.

GRANT, Edward, 1982. The Effect of the Condemnation of 1277. In: KRETZMANN, Norman, KENNY, Anthony, PINBORG, Jan \& STUMP, Eleonore. The Cambridge History of Later Medieval Philosophy: From the Rediscovery of Aristotle to the Disintegration of Scholasticism, 1100-1600, Cambridge: Cambridge University Press, pp. 537-539. ISBN 0521369339. 
IDFI, 2019. Stalinism in Soviet Schools and the Pupils' Case. Article published online by the Institute for Development of Freedom of Information, Tiblisi, Georgia. Available at: https://idfi.ge/en/stalinism_in_soviet_schools.

LEWIS, Steven \& HOLLOWAY, Jessica 2019. Datafying the Teaching 'Profession': Remaking the Professional Teacher in the Image of Data. Cambridge Journal of Education. Taylor and Francis, 49(1), pp. 35-51.

Mac CULLOCH, Diarmaid, 2009. A History of Christianity: The First Three Thousand Years. London: Allen Lane. ISBN 978-0141021898.

McLEAN, Eden K., 2018. Mussolini's Children: Race and Elementary Education in Fascist Italy. Lincoln and London: University of Nebraska Press. ISBN 978-1496206428.

MUSSOLINI, Benito, 1932. The Doctrine of Fascism. Co-authored by Giovanni Gentile. Full text available at: https://sjsu.edu/faculty/wooda/2B-HUM/Readings/ The-Doctrine-of-Fascism.pdf.

THIJSSEN, Hans, 2018. “Condemnation of 1277”. The Stanford Encyclopedia of Philosophy (Winter 2018 Edition), Edward N. Zalta (ed.). Available at: https://plato.stanford.edu/archives/win2018/entries/condemnation/.

PLATO, 2000. The Republic. Translated by P. Shorey. Loeb Classical Library, Cambridge MA: Harvard University Press. ISBN 9708674993044.

PRIMO De RIVERA, José Antonio, 1933/2020. “Discurso de José Antonio Primo de Rivera exponiendo los puntos fundamentales de Falange española, pronunciado en el Teatro de la Comedia de Madrid, el día 29 octubre de 1933". Full text available at: http://www.segundarepublica.com/index.php?opcion=6\&id=78.

ROBERTSON, Susan Lee \& SØRENSEN, Tore 2018. Global Transformations of the State, Governance and Teachers' Labour: Putting Bernstein's Conceptual Grammar to Work. European Educational Research Journal. Sage 17 (4), pp. 470-488. ISSN 1474-9041.

SAHLBERG, Pasi, 2015. Finnish Lessons: What Can the World Learn from Educational Change in Finland?. Second edition. New York: Teachers College Press. ISBN 978-0807755853. 